\title{
PENGARUH WORD OF MOUTH DAN PROMOSI TERHADAP MINAT MENABUNG ANGGOTA DI KSPS BMT UGT SIDOGIRI CABANG PAMEKASAN
}

\author{
Zainullah $^{1}$, Achmad Sani Supriyanto ${ }^{2}$ \& Siswanto $^{3}$ \\ ${ }^{1,2 \& 3}$ Universitas Islam Negeri (UIN) Maulana Malik Ibrahim Malang \\ Email: zainullahzibok@gmail.com,achmad_sani72@gmail.com, \\ siswanto@pbs.uin-malang.ac.id
}

\begin{abstract}
ABSTRAK
Penelitian ini meneliti tentang pengaruh word of mouth dan promosi terhadap minat menabung anggota di KSPT BMT UGT Sidogiri Cabang Pamekasan. Tujuan penelitian ini untuk mengetahui pengaruh word of mouth dan promosi terhadap minat menabung anggota. Penelitian ini menggunakan pendekatan kuantitatif dengan analisis regresi linier berganda. Hasil penelitian ini yaitu berdasarkan hasil uji-t pada setiap variabel yang ada yaitu dihasilkan pada variabel word of mouth $\left(\mathrm{X}_{1}\right)$ menghasilkan nilai $t_{\text {hitung }} 3.501>t_{\text {tabel }} 1,966$ dengan nilai signifikan $0,01<0,05$ dan variabel promosi $\left(\mathrm{X}_{2}\right)$ dihasilkan nilai $\mathrm{t}_{\text {hitung }} 3.029>\mathrm{t}_{\text {tabel }} 1,966$, dengan nilai signifikan $0,003<0,05$. Maka dapat ditarik kesimpulan bahwa word of mouth dan promosi memiliki pengaruh yang signifikan terhadap minat menabung di KSPS BMT UGT Sidogiri Cabang Pamekasan. Berdasarkan adjust $R^{2}$ adalah 0,076 atau 7.6\%. Hal ini berarti sebesar 7,6\% kemampuan model regresi pada penelitian ini dalam menerangkan variabel dependen. Artinya $7.6 \%$ variabel, word of mouth dan promosi berpengaruh terhadap minat menabung. Sedangkan sisanya $(100 \%-7.6 \%=92.4 \%)$ dipengaruhi oleh variabel-variabel lainnya yang tidak diperhitungkan dalam analisis penelitian ini. Serta dalam penelitian ini ditemukan bahwa variabel yang paling berpengaruh adalah word of mouth.
\end{abstract}

Kata Kunci : Word Of Mouth, Promosi, Minat Menabung.

\begin{abstract}
This study examines the effect of word of mouth and promotion on members' interest in saving at KSPT BMT UGT Sidogiri Pamekasan Branch. The purpose of this study is to determine the effect of word of mouth and promotion on members' saving interest. This study uses a quantitative approach with multiple linear regression analysis. The results of this study can be based on the results of the $t$ test on each of the existing variables that is generated in the word of mouth variable (X1) produces a t-count value of 3,501 > t-table 1,966 with a significant value of $0.01<0.05$ and the promotion variable (X2) results in a $t$-count value of 3,029 > t-table 1,966, with a value of significant $0.003<$ 0.05. So it can be concluded that word of mouth and promotion have a significant influence on interest in saving at KSPS BMT UGT Sidogiri Pamekasan Branch. Based on Adjust R2 is 0.076 or 7.6\%. This means $7.6 \%$ of the ability of the regression model in this study to explain the dependent variable. This means that $7.6 \%$ of variables, word of mouth and promotion have an effect on interest in saving. While the rest $(100 \%-7.6 \%=92.4 \%)$ is influenced by other variables that are not taken into account in the analysis of this study. And in this study it was found that the most influential variable was word of mouth.
\end{abstract}

Keywords: Word of Mouth, Promotion, Interest in Saving. 


\section{PENDAHULUAN}

Pemasaran merupakan hal yang penting dalam suatu perusahaan, maka dari itu pemasaran yang efektif dan efisien didapatkan melalui upaya-upaya tertentu seperti mempertimbangkan perilaku konsumen, dalam pemasaran konsumen dipandang menjadi bagian penting dalam mengukur suksesnya suatu pemasaran, selain menjadi objek pemasaran, konsumen juga memiliki bagian dalam mempengaruhi berbagai perusahaan untuk menerapkan berbagai upaya pemasarannya sehingga menghasilkan sebuah keunggulan yang dapat memberikan ketertarikan bagi konsumen.

Perilaku konsumen pun bermacammacam adanya yaitu konsumen yang sifatnya konsumtif, jenis ini biasanya mereka yang penting dapat membeli apa yang diinginkan, terdapat beberapa tahapan-tahapan perilaku konsumen dalam memilih suatu produk, yaitu mencari informasi terkait produk, membandingkan, hingga menentukan keputusan dalam menggunakan produk tersebut.

Membuat target pemasaran sudah dianggap penting dalam sebuah perusahaan, berbagai macam cara dilakukan agar tersampaikannya informasi tentang suatu produk seperti halnya dengan cara bauran pemasaran serta komunikasi pemasaran di antaranya adalah produk, harga, promosi, ditribusi (Kotler dan Amstrong, 2010). Selain itu juga pemasaran langsung, promosi dan word of mouth atau penyampaian informasi dari lisan ke lisan, yang mana menjadi sebuah jalur komunikasi pemasaran, dalam hal bertukar pikiran antara konsumen satu dengan konsumen lainya, yang dapat dilakukan perusahaan dalam mempengaruhi konsumen terhadap permintaan produk, khususnya untuk mempengaruhi konsumen dalam menggunakan suatu produk.

Kemudian dalam meningkatkan mutu serta efektifitas dalam pemasaran, maka lembaga atau perusahaan akan meningkatkan kualitas, mulai dari produk, promosi bahkan komunikasi pemasaran secara langsung serta word of mouth, hal ini tentunya akan memberikan kemudahan konsumen dalam menerima informasi tentang suatu produk dengan cepat, sehingga sebuah target dari pemasaran menjadi tercapai.

\section{KSPS BMT UGT Sidogiri} merupakan suatu lembaga keuangan yang bergerak dalam simpanan dan pembiayaan dengan sistem syariah dalam hal ini disebut koperasi. Perkoperasian sudah jelas prospek kedepannya lembaga keuangan non bank seperti perkoperasian yang mana telah diatur dalam UU No. 25 tahun 1992 tentang perkoperasian (Yusuf dan Wiroso, 2011). KSPS BMT UGT Sidogiri Cabang Pamekasan memiliki berbagai produk didalamnya, seperti, tabungan umum, tabungan berjangka, tabungan qurban, pembiayaan dan lainnya.

KSPS BMT UGT Sidogiri Cabang Pamekasan menerapkan pemasaran dengan cara bauran pemasaran serta adanya komunikasi pemasaran, seperti halnya promosi, melalui cara pemasaran baik tenaga pemasar maupun secara iklan, brosur bahkan word of mouth, selain itu keunggulan produk ikut serta menjadi bahan dalam menonjolkan suatu produk yang mana berupa sebuah fasilitas tambahan yaitu adanya fasilitas asuransi pada anggota yang menabung di KSPS BMT UGT Sidogiri Cabang Pamekasan, seperti pada tabungan umum syariah, tabungan tarbiyah, tabungan saham dan tabungan masa depan sehingga dapat menarik minat anggota di KSPS BMT UGT Sidogiri Cabang Pamekasan, hal ini merupakan suatu keunggulan yang berbeda dengan yang lainnya yaitu adanya sebuah fasilitas jaminan asuransi dengan saldo minimal Rp. 500.000,- dengan premi ditanggung oleh KSPS BMT Sidogiri Cabang Pamekasan, selain itu juga peneliti mencoba melihat sejauh mana pengaruh dan membandingkan besar pengaruh pada setiap cara pemasaran yang ada.

Tentunya ini menjadi hal yang menarik untuk peneliti teliti, selain itu juga peneliti mencoba menggabungkan dengan 
model pemasaran yang lain seperti promosi dan word of mouth (dari mulut ke mulut), apabila melihat jumlah anggota di KSPS BMT Sidogiri Cabang Pamekasan anggota yang aktif menabung sebesar 4637 anggota. Adapun yang menjadi poin penting apakah minat menabung anggota dipengaruhi oleh model-model pemasaran di atas, maka dari itu penilitian ini berjudul Pengaruh word of mouth dan promosi terhadap minat menabung anggota di KSPS BMT UGT Sidogiri Cabang Pamekasan.

Penelitian tentang word of mouth dan promosi juga pernah diteliti oleh Said (2016) dengan judul penelitian pengaruh brand image, word of mouth, dan iklan terhadap minat menabung di BMT SeKabupaten Demak, penelitian ini menggunakan pendekatan kuantitatif dengan metode angket yang disebarkan pada anggota BMT Se-Kabupaten Demak sebanyak 312 responden. Sampel diambil dengan menggunakan teknik purposive sampling. Data penelitian dianalisis dengan menggunakan analisis regresi. Hasil penelitian ini menemukan bahwa brand image memiliki pengaruh terhadap minat menabung di BMT Se-Kabupaten Demak ini dibuktikan bahwa nilai thitung sebesar 2,115 $>$ t-tabel sebesar 1,982. Kedua, word of mouth memiliki pengaruh terhadap minat menabung di BMT Se-Kabupaten Demak dengan t-hitung sebesar 3,270 > t-tabel sebesar 1,982. Ketiga, iklan memiliki pengaruh terhadap minat menabung di BMT Se-Kabupaten Demak dengan t-hitung 2,944 $>$ t-tabel 1,982.

Penelitian yang dilakukan oleh Prasetyo dan Wahyuati (2016) mengenai pengaruh strategi promosi dan word of mouth terhadap keputusan pembelian pada Kopiganes, perusahaan melakukan promosi agar dapat mencapai tujuan yang diinginkan. Hal lain yang juga mempengaruhi pencapaian tujuan perusahaan adalah promosi penjualan dan kemampuan pramuniaga yang dilakukan oleh setiap perusahaan. Sehingga apabila pelanggan dapat menerima produk yang dihasilkan oleh perusahaan dengan baik maka akan timbul word of mouth yang baik juga. Sampel yang di ambil sebanyak 100 orang pelanggan Café Kopiganes dengan mengunakan rumus slovin sebagai teknik pengambilan sampel. Hasil penelitian ini menunjukan tingkat signifikan terjadi pada variabel $\mathrm{X}$ (advertising, sales promotion, personal selling dan word of mouth) terhadap variabel Y (keputusan pembelian). Pada hasil regresi didapat bahwa variabel word of mouth merupakan variabel yang paling signifikan dalam penelitian.

\section{TINJAUAN PUSTAKA}

\section{Pemasaran}

Istilah pemasaran sering kali dikaitkan dengan penjualan (sales), sales promotion, iklan, promosi, atau produk. Bahkan seringkali orang menyamakan profesi marketer (pemasar) dengan sales (penjual). Namun sebenarnya arti dari pemasaran tidak sesempit yang dianggap banyak orang, pemasaran merupakan "suatu seni tentang pemasaran menjual produk", sehingga pemasaran proses penjualan yang dimulai dari perencanaan sampai dengan produk itu terjual.

Pemasaran merupakan suatu cara atau metode sebagai sutau proses sosial dan manajerial yang membuat individu dan kelompok memperoleh apa yang mereka inginkan, lewat penciptaan dan pertukaran timbal balik produk dan nilai dengan orang lain. (Kotler \& Amstrong, 2010)

Dari definisi di atas dapat ditarik kesimpulan bahwa pemasaran merupakan suatu cara atau metode, baik bersifat individu maupun bersifat kelompok, serta menjadi pegangan atau kunci dari suksesnya suatu usaha, dalam menguasai pasar, biasanya melalui kegiatan mempromosikan suatu produk baik langsung maupun tidak langsung seperti menggunakan komunikasi pemasaran atau yang lainnya.

\section{Pengertian Word of Mouth}

Word of mouth adalah sebuah pertukaran komentar pemikiran, atau ide- 
idenya antara dua konsumen atau lebih, yang satupun bagian dari keduanya bukan bagian dari sumber pemasaran (Said, 2016).

Word of mouth merupakan komunikasi pribadi tentang sebuah produk antara pembeli sasaran dan tetangga, temanteman, anggota keluarga dan rekannya. Mayoritas orang-orang akan bercerita, bertukar pikiran, dan saling tukar informasi tentang pengalaman mereka kepada orang yang dikenal (Juniantoko \& Supriono, 2017).

Dari dua pendapat di atas maka dapat disimpulkan bahwa yang dimaksud dengan word of mouth adalah suatu bentuk komunikasi antara dua orang atau lebih, yang mana dalam keduanya terjadinya sebuah pertukaran pikiran yaitu adanya sebuah penyampaian informasi yang biasanya dapat berupa merekomendasikan sebuah informasi tentang suatu produk tertentu, namun keduanya bukanlah bagian dari sumber pemasaran.

Sedangkan menurut Mowen dan Minor (2002 mengemukakan (word of mouth) adalah pertukaran komentar pemikiran, atau ide-ide diantara dua konsumen atau lebih, yang tidak satupun merupakan sumber pemasaran. Menurut Godes dan Mayzlin, dua elemen yang digunakan untuk mengukur word of mouth, yaitu volumen dan dispersion.

Menurut Sumardi dalam Sari (2012) word of mouth adalah kegiatan pemasaran yang memicu konsumen untuk membicarakan, mempromosikan, merekomendasikan hingga menjual merek suatu produk kepada calon konsumen lainnya.Terdapat dua sumber utama yang menghasilkan word of mouth diantaranya yaitu reference group dan opinion leader. Peter dan Olson (2000) menegaskan bahwa sebuah kelompok terdiri dari dua atau lebih orang yang berinteraksi satu sama lain untuk mencapai tujuan yang sama, serta mempunyai latar belakang yang sama dan tidak berbadan hukum.

\section{Pengertian Promosi}

Promosi merupakan kegiatan marketing mix yang terakhir. Suatu produk yang telah diciptakan kemudian harga telah ditetapkan serta lokasi atau tempat sudah ditentukan maka produk tersebut sudah siap untuk dipromosikan. Karena dengan melalui sarana promosi, masyarakat akan lebih tahu dan paham akan kehadiran yang telah diproses sedemikian rupa. Promosi biasanya terdiri dari manfaat, harga, dimana didapatkan, karakteristik dari produk sampai dengan kelebihan-kelebihan yang dimiliki oleh produk kita dengan tujuan sebagai pembeda terhadap produk yang serupa lainnya (Kasmir, 2008).

Promosi adalah suatu komunikasi dari penjual dan pembeli yang berasal dari informasi yang tepat yang bertujuan untuk merubah sikap dan tingkah laku pembeli yang tadinya tidak mengenal menjadi mengenal sehingga menjadi pembeli dan tetap mengingat produk tersebut (Laksana, 2008).

Promosi adalah suatu usaha dari pemasaran dalam menginformasikan dan mempengaruhi orang atau pihak lain, sehingga tertarik untuk melakukan transaksi atau pertukaran produk barang atau jasa yang di pasarkan biasanya berupa periklanan, penjualan personal, serta cara lainnya.

Promosi adalah suatu kegiatan untuk meningkatkan penjualan. Biasanya dalam kegiatan promosi pemilik usaha memuji barang dan mengemukakan keungggulan barang yang di jualnya.

Dari dua pendapat di atas dapat disimpulkan bahwa promosi adalah suatu usaha pemasaran dalam menginformsikan suatu produk tertentu baik barang maupun jasa yang mana tujuannya dengan semakin banyaknya orang calon konsumen yang mengetahui produk tersebut sehingga meningkatkan jumlah penjualan. 


\section{Pengertian Minat}

Menurut Kotler, minat membeli adalah rangsangan internal yang kuat memotivasi tindakan (Nuvidiana, 2015). Sedangkan menurut Kinnear \& Taylor (1995), minat beli merupakan tahap kecenderungan responden untuk bertindak sebelum keputusan membeli benar-benar dilaksanakan.

Berberapa pendapat di atas dapat disimpulkan yang dimaksud minat adalah sebuah rangsangan internal responden dalam mencoba atau menggunakan suatu barang atau jasa.

\section{METODE PENELITIAN}

Penelitian ini menggunakan pendekatan kuantitatif. Penelitian kuantitatif biasa dikenal dengan peneltian yang bersifat angka-angka (Abdullah \& Saebani, 2014), dengan analisis regresi linier berganda, yang bertujuan untuk mengetahui besarnya pengaruh word of mouth, dan promosi terhadap minat menabung anggota di KSPS BMT UGT Sidogiri Cabang Pamekasan.

\section{Populasi dan Sampel}

Populasi dari penelitian ini adalah anggota yang menggunakan fasilitas tabungan di BMT UGT Sidogiri Cabang Pamekasan. Berdasarkan informasi yang diperoleh, jumlah anggota, yang menabung sebanyak 4637 anggota.

Kemudian penelitian ini, menggunakan teknik pengambilan sampel Accidental Sampling, yaitu pengambilan sampel dengan cara menjadikan siapa saja individu/anggota yang dapat dijangkau atau ditemui, asalkan sampel yang akan dijadikan objek sesuai untuk diteliti. Penentuan jumlah sampel ditentukan dengan menggunakan rumus slovin yaitu:

$$
\mathrm{n}=\frac{N}{1+N e^{2}}
$$

Keterangan:

$$
\begin{aligned}
& \mathrm{n} \text { = Ukuran Sampel Umum } \\
& \mathrm{N}=\text { Ukuran populasi } \\
& \mathrm{e}=\text { Persentase kelonggaran ketidak }
\end{aligned}
$$

$$
\begin{aligned}
& \mathrm{n}=\frac{4637}{1+4637(0,0025)} \\
& \mathrm{n}=\frac{4637}{1+11.5925} \\
& \mathrm{n}=\frac{4637}{12.5925} \\
& \mathrm{n}=368
\end{aligned}
$$

Jadi, sampel dalam penelitian ini jika dibulatkan sebanyak 368 sampel.

\section{HASIL PENELITIAN}

\section{Uji Normalitas}

Berdasarkan hasil normatif pengujian normalitas dalam penelitian ini menggunakan grafik normal probabilityplot dan one-sampel kolomogrov-smirnov. Hasil uji normalitas dengan menggunakan grafik normal probabilityplot, yaitu: 


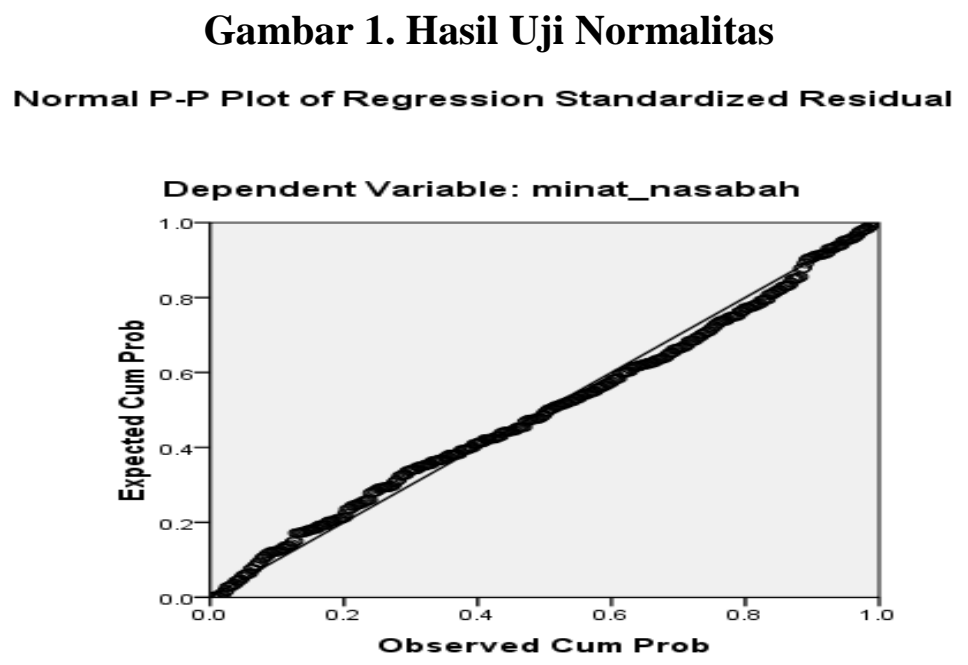

Sumber : Data Olahan (2021)

Berdasarkan gambar di atas dari hasil output SPSS 16, pada grafik normal probability plot menunjukkan bahwa data (titik-titik) menyebar di sekitar garis diagonal dan mengikuti arah garis diagonal, maka dapat disimpulkan model regresi memenuhi asumsi normalitas.

\section{Uji Multikolinearitas}

Berdasarkan hasil pengujian multikolinearitas, diperoleh nilai tolerance variabel bebas word of mouth $\left(\mathrm{X}_{1}\right)$ dan promosi $\left(\mathrm{X}_{2}\right)$ masing - masing yaitu, word of mouth $\left(\mathrm{X}_{2}\right)$ 0.969, promosi (X3) 0.850 dan nilai VIF masing-masing yaitu $\left(\mathrm{X}_{1}\right) 1.156$,
$\left(\mathrm{X}_{2}\right) 1.033\left(\mathrm{X}_{3}\right)$ 1.177, hal ini menunjukkan nilai tolerance masing-masing yaitu word of mouth 0,969>0,10 dan promosi $0.850>$ 0,10 . Nilai VIF masing-masing yaitu word of mouth $1.033<10$ dan promosi $1.177<10$, sehingga dapat disimpulkan bahwa antar variabel bebas tidak terjadi multikolinearitas.

\section{Regresi Linear Berganda}

Adapun hasil dari uji regresi berganda dari penelitian ini terdapat dalam tabel di bawah ini :

\section{Tabel 1. Hasil Uji Regresi Berganda}

Coefficients $^{\mathrm{a}}$

\begin{tabular}{|c|c|c|c|c|c|}
\hline \multirow[b]{2}{*}{ Model } & \multicolumn{2}{|c|}{ Unstandardized Coefficients } & \multirow{2}{*}{$\begin{array}{l}\text { Standardized Coefficients } \\
\text { Beta }\end{array}$} & \multirow[b]{2}{*}{$\mathbf{T}$} & \multirow[b]{2}{*}{ Sig. } \\
\hline & B & Std. Error & & & \\
\hline 1 (Constant) & 29.523 & 2.966 & & 9.954 & .000 \\
\hline word_of_mouth & .479 & .137 & .178 & 3.501 & .001 \\
\hline Promosi & .169 & .056 & .164 & 3.029 & .003 \\
\hline
\end{tabular}

Sumber : Data Olahan (2021)

Berdasarkan hasil analisis regresi linear berganda pada tabel 1 di samping, diperoleh koefisien variabel independen word of mouth $(\mathrm{X} 1)=0,479$ dan promosi $(X 2)=0,169$ serta konstanta sebesar 29.523. Jadi, model persamaan regresi yang diperoleh dalam penelitian ini, sebagai berikut :

$$
\mathrm{Y}=29.52+\left(0.479 \mathrm{X}_{1}\right)+\left(0.169 \mathrm{X}_{2}\right)
$$

Model persamaan regresi linear berganda tersebut dapat diuraikan sebagai berikut :

a. $\mathrm{a}=29.52$, konstanta sebesar 29.52 menyatakan bahwa jika variabel $X$ (independen) tidak dipertimbangkan (bernilai nol), maka minat menabung di 
KSPS BMT UGT Sidogiri Cabang Pamekasan sebesar 29.52 atau 29.52\%.

b. Model persamaan tersebut, nilai koefisien regresi untuk semua variabel mempunyai pengaruh, berarti berpengaruh keseluruhan variabel independen dan variabel dependen adalah positif. Sifat pengaruh yang positif menunjukkan bahwa apabila terjadi peningkatan terhadap variabel independen maka minat menabung anggota di KSPS BMT UGT Sidogiri Cabang Pamekasan juga akan meningkat.

c. $b_{2}=0,479$ nilai koefisien regresi variabel word of mouth $\left(\mathrm{X}_{1}\right)$ sebesar 0,479 . Hal ini berarti bahwa jika terjadi peningkatan pada variabel tersebut sebesar $1 \%$ maka minat menabung anggota di KSPS BMT UGT Sidogiri Cabang Pamekasan juga akan mengalami peningkatan sebesar 0,479 atau $47,9 \%$ dengan asumsi variabel yang dianggap tetap.

d. $b_{3}=0,169$ nilai koefisien regresi variabel promosi $\left(\mathrm{X}_{2}\right)$ sebesar 0,169. Hal ini berarti bahwa jika terjadi terjadi peningkatan pada variabel tersebut sebesar $1 \%$ maka minat menabung anggota di KSPS BMT UGT Sidogiri Cabang Pamekasan juga akan mengalami penurunan sebesar 0,169 atau $16,9 \%$ dengan asumsi variabel yang dianggap tetap.

e. Dari koefisien regresi masing-masing variabel independen $(0.174,0.479,0.164$ dan 0.169) menunjukkan bahwa variabel, word of mouth dan promosi mempunyai pengaruh positif terhadap minat menabung di KSPS BMT UGT Sidogiri Cabang Pamekasan.

\section{Uji Signifikan Parsial (Uji t)}

Berdasarkan hasil uji signifikan parsial (Uji t) variabel word of mouth $\left(\mathrm{X}_{1}\right)$ diperoleh $t_{\text {hitung }}$ sebesar 3.501 dengan taraf signifikan 0,01 . Nilai $t_{\text {tabel }}$ untuk model regresi diatas yaitu 1,966. Hasil uji tersebut menunjukkan bahwa nilai signifikan $0,01<$ 0,05 dan nilai $t_{\text {hitung }} 3.501>t_{\text {tabel }} 1,966$. Disimpulkan bahwa variabel word of mouth berpengaruh signifikan terhadap minat menabung di KSPS BMT UGT Sidogiri Cabang Pamekasan.

Variabel promosi $\left(\mathrm{X}_{2}\right)$ diperoleh $\mathrm{t}_{\text {hitung }}$ sebesar 3.029 dengan taraf signifikan 0,003. Nilai $t_{\text {tabel }}$ untuk model regresi diatas yaitu 1,966. Hasil uji tersebut menunjukkan bahwa nilai signifikan $0,003<0,05$ dan nilai $t_{\text {hitung }}$ $3.029>t_{\text {tabel }}$ 1,966. Disimpulkan bahwa variabel promosi berpengaruh signifikan terhadap minat menabung di KSPS BMT UGT Sidogiri Cabang Pamekasan.

\section{Uji F}

Berdasarkan hasil uji $\mathrm{F}$ hasil tersebut diperoleh nilai $F_{\text {hitung }}$ sebesar 11.573 dengan tingkat signifikan sebesar 0,000 (lebih kecil dari signifikan 0,05$)$, sedangkan nilai $F_{\text {tabel }}$ sebesar 2,62. Berarti nilai $F_{\text {hitung }} 11.573>$ $F_{\text {tabel }} 2,62$ dan tingkat signifikan $0,000<0,05$ sehingga keputusannya adalah variabel $X$ (word of mouth dan promosi) secara simultan berpengaruh dan signifikan terhadap minat menabung di KSPS BMT UGT Sidogiri Cabang Pamekasan.

\section{Koefisien Determinasi $\left(\mathbf{R}^{2}\right)$}

Koefisien determinasi $\left(\mathrm{R}^{2}\right)$ digunakan untuk mengukur seberapa jauh kemampuan model dalam menerangkan variasi variabel dependen dengan melihat Adjust $R$ Square. Berikut hasil koefisien determinasi 
Tabel 2. Hasil Koefisien Determinasi

\begin{tabular}{l|rrrr}
\hline \multicolumn{5}{c}{ Model Summary $^{\mathbf{b}}$} \\
\hline Model & \multicolumn{1}{c}{ R } & \multicolumn{1}{c}{ R Square } & Adjusted R Square & \multicolumn{2}{c}{ Std. Error of the Estimate } \\
\hline 1 & $.275^{\mathrm{a}}$ & .076 & .068 & 5.58589 \\
\hline a. Predictors: (Constant), X2, X1 & & & \\
\hline b. Dependent Variable: $\mathrm{Y}$ & & & \\
\hline
\end{tabular}

Sumber : Data Olahan (2021)

Berdasarkan tabel tersebut, hasil analisis koefisien determinasi terlihat bahwa besarnya Adjust $R^{2}$ adalah 0,076 atau $7.6 \%$. Hal ini berarti sebesar $7,6 \%$ kemampuan model regrlesi pada penelitian ini dalam menerangkan variabel dependen. Artinya $7.6 \%$ variabel word of mouth dan promosi berpengaruh terhadap minat menabung. Sedangkan sisanya $(100 \%-7.6 \%=92.4 \%)$ dipengaruhi oleh variabel-variabel lainnya yang tidak diperhitungkan dalam analisis penelitian ini.

\section{PEMBAHASAN}

Pengaruh Word of Mouth dan Promosi Terhadap Minat Menabung di BMT UGT Sidogiri Cabang Pamekasan

Pengaruh word of mouth $\left(\mathrm{X}_{1}\right)$ dan promosi $\left(\mathrm{X}_{2}\right)$ terhadap minat menabung anggota di BMT UGT Sidogiri Cabang Pamekasan, dapat dilihat dari nilai standar koefisien variabel, word of mouth dan promosi terhadap minat menabung anggota yaitu bernilai sebesar $\left(X_{1}\right)=0,178$ serta $\left(X_{2}\right)$ $=0,164$. Berarti variabel, word of mouth dan promosi mempunyai hubungan yang positif terhadap minat menabung, selanjutnya berdasarkan hasil analisis uji $\mathrm{t}$ (secara parsial) diketahui variabel-variabel word of mouth $\left(\mathrm{X}_{1}\right)$ diperoleh $\mathrm{t}_{\text {hitung }}$ sebesar 3.501 dengan taraf signifikan 0,01. Nilai $t_{\text {tabel }}$ untuk model regresi diatas yaitu 1,966. Hasil uji tersebut menunjukkan bahwa nilai signifikan $0,01<0,05$ dan nilai $t_{\text {hitung }} 3.501$ $>t_{\text {tabel }}$ 1,966. Disimpulkan bahwa variabel word of mouth berpengaruh siginifikan terhadap minat menabung di KSPS BMT UGT Sidogiri Cabang Pamekasan. Hasil penelitian ini sejalan dengan penelitan yang di lakukan oleh Said (2016) yang memperoleh hasil bahwa variabel word of mouth berpengaruh signifikan terhadap minat menabung.

Variabel promosi $\left(\mathrm{X}_{2)}\right.$ diperoleh $\mathrm{t}_{\text {hitung }}$ sebesar 3.029 dengan taraf signifikan 0,003. Nilai $t_{\text {tabel }}$ untuk model regresi diatas yaitu 1,966. Hasil uji tersebut menunjukkan bahwa nilai signifikan $0,003<0,05$ dan nilai $t_{\text {hitung }}$ $3.029>t_{\text {tabel }}$ 1,966. Disimpulkan bahwa variabel promosi berpengaruh signifikan terhadap minat menabung di KSPS BMT UGT Sidogiri Cabang Pamekasan. Hasil penelitian ini sejalan dengan penelitian yang dilakukan oleh Asiyah (2020), Ortega (2017) dan Rahayu (2018) dimana promosi berpengaruh signifikan terhadap minat menabung.

Pengaruh word of mouth dan promosi terhadap minat menabung anggota di KSPS BMT UGT Sidogiri Cabang Pamekasan, berdasarkan hasi uji $\mathrm{F}$ tersebut diperoleh nilai $F_{\text {hitung }}$ sebesar 11.573 dengan tingkat signifikan sebesar 0,000 (lebih kecil dari signifikan 0,05), sedangkan nilai $\mathrm{F}_{\text {tabel }}$ sebesar 2,62. Berarti nilai $F_{\text {hitung }} 11.573>$ $F_{\text {tabel }} 2,62$ dan tingkat signifikan $0,000<$ 0,05 sehingga keputusannya adalah variabel $\mathrm{X}$ (word of mouth dan promosi) secara simultan berpengaruh dan signifikan terhadap minat menabung di KSPS BMT UGT Sidogiri Cabang Pamekasan.

Berdasarkan Adjust $R^{2}$ adalah 0,076 atau $7.6 \%$. Hal ini berarti sebesar $7,6 \%$ kemampuan model regresi pada penelitian ini dalam menerangkan variabel dependen. Artinya $7.6 \%$ variabel jaminan asuransi, word of mouth dan promosi berpengaruh 
terhadap minat menabung. Sedangkan sisanya $(100 \%-7.6 \%=92.4 \%)$ dipengaruhi oleh variabel-variabel lainnya yang tidak diperhitungkan dalam analisis penelitian ini.

\section{Variabel yang Paling Berpengaruh Terhadap Minat Menabung di BMT UGT Sidogiri Cabang Pamekasan}

Untuk mengetahui variabel yang paling berpengaruh terhadap kinerja karyawan di BMT UGT Sidogiri cabang Pamekasan, maka dapat dilihat dari hasil regresi linear berganda dengan melihat nilai koefisien dari masing-masing variabel independen dan dependen. Koefisien regresi untuk variabel variabel word of mouth $\left(\mathrm{X}_{2}\right)$ sebesar 3.501 dengan taraf signifikan 0,001 $<0,05$ dan variabel promosi $\left(\mathrm{X}_{2}\right)$ sebesar 3.029 dengan taraf signifikan 0,003 $<0,05$.

Maka dapat disimpulkan bahwa dalam penelitian ini yaitu pengaruh, word of mouth dan promosi terhadap minat menabung di BMT UGT Sidogiri Cabang Pamekasan, dari hasil uji di atas maka dapat di simpulkan bahwa variabel yang paling berpengaruh adalah variabel word of mouth $\left(\mathrm{X}_{1}\right)$. Terhadap minat menabung di KSPS BMT UGT Sidogiri Cabang Pamekasan.

\section{KESIMPULAN}

Berdasarkan hasil analisis data dan pengujian hipotesis tentang "pengaruh word of mouth dan promosi terhadap minat menabung di KSPS BMT UGT Sidogiri Cabang Pamekasan", maka dapat ditarik beberapa kesimpulan yaitu:

a. Berdasarkan hasil uji-t pada setiap variabel yang ada yaitu di hasilkan pada variabel word of mouth mempengaruhi terhadap minat menabung.

b. Berdasarkan koefisien determinasi $\left(\mathrm{R}^{2}\right)$ dimana pada penelitian ini word of mouth dan promosi berpengaruh terhadap minat menabung. Sedangkan sisanya $(100 \%-7.6 \%=92.4 \%)$ kemungkinan dipengaruhi oleh variabel-variabel lainnya yang tidak diperhitungkan dalam analisis penelitian ini. c. Berdasarkan hasil regresi linear berganda dengan melihat nilai koefisien dari masing-masing variabel independen dan dependen. Maka dapat disimpulkan bahwa dalam penelitian ini, dari hasil uji di atas maka dapat disimpulkan bahwa variabel yang paling berpengaruh adalah variabel word of mouth $\left(\mathrm{X}_{2}\right)$ terhadap minat menabung di KSPS BMT UGT Sidogiri Cabang Pamekasan.

\section{DAFTAR PUSTAKA}

Abdullah, Boedi dan Saebani, Beni Ahmad. 2014. Metode Penelitian Ekonomi Islam Muamalah. CV. Pustaka Setia. Bandung.

Asiyah, Sitti., \& Riyadi, Yohansyah Adiputra. 2020. Pengaruh Promosi dan Kualitas Pelayanan terhadap Minat Menabung Masyarakat keluruhan Siranindi di Bank Muamalat Indonesia Palu Sulawesi Tengah. Al-Kharaj : Journal of Islamic Economics and Business, 02(01), p. 16-33.

Juniantoko, Ardy Dwi \& Supriono. 2017. Pengaruh Word of Mouth Terhadap Minat Beli Serta Dampaknya Pada Keputusan Pembelian (Survei Pada Konsumen Waroeng Latte dan The Cemiland di Kota madiun. Jurnal Administrasi Bisnis (JAB), 53(2), p. 11-18.

Kasmir. 2008. Pemasaran Bank, Edisi revisi Cet.III. Prenada Media Group. Jakarta.

Kinnear, Thomas C., dan Taylor, James R. 1995. Riset Pemasaran. Alih Bahasa. Yohanna Lamarto; Jilid II. Erlangga. Jakarta.

Kotler, Philip., dan Amstrong, Gary. 2010 Prinsip-Prinsip Pemasaran. Erlangga. Jakarta.

Laksana, Fajar. 2008. Manajemen Pemasaran. Cet. I. Graha Ilmu. Yogyakarta. 
Mowen, Jhon dan Michael, Minor. 2002. Perilaku Konsumen, Edisi 5 Jilid 1\&2. (Alih Bahasa Lina Salim). Erlangga. Jakarta.

Nuvidiana, Rahma. 2015. Pengaruh Word of Mouth Terhadap Minat Beli Serta Dampaknya Pada Keputusan Pembelian (Survei Pada Konsumen Republica Cafe Malang Jalan Mt. Haryono gg. xi Malang), Jurnal Administrasi Bisnis (JAB). 22 (2). P. $1-8$.

Ortega, Daniel., \& Alhifni, Anas. 2017. Pengaruh Media Promosi Perbankan Syariah terhadap Minat menabung Masyarakat di Bank Syariah. EQUILIBRIUM: Jurnal Ekonomi Syariah, 5(1), p. 87-98.

Peter, Paul J. dan Jerry C. Olson. 2000. Consumer Behavior: Perilaku Konsumen dan Strategi Pemasaran. Dialih bahasakan oleh Damos Sihombing. Erlangga. Jakarta.

Prasetyo, Antoni., \& Wahyuati, Aniek. 2016. Pengaruh Strategi Promosi dan Word of Mouth Terhadap Keputusan Pembelian Pada Kopiganes. Jurnal Ilmu dan Riset Manajemen, 5(1), p. 1-17.

Rahayu, Ovi. 2018. Pengaruh Promosi dan Pelayanan terjadap Minat Menabung pada Anggota BMT BINAMAS Purworejo. OIKONOMIA, 7(1), p. 127-132.

Said. Abu. 2016. Pengaruh Brand Image, Word of Mouth dan Iklan terhadap minat Menabung Di BMT SeKabupaten Demak, EQUILIBRIUM: Jurnal Ekonomi Syariah, 4(2), p. 318-333.

Sari, Ratna Dwi Kartika. 2012. Analisis Pengaruh Kualitas Produk, Persepsi Harga, dan Word of Mouth Cummunication Terhadap Keputusan Pembelian Mebel Pada CV. Mega Jaya Mebel Semarang. Jurnal. Universitas Diponegoro.
Yusuf \& Wiroso. 2011. Bisnis syariah. Mitra Wacana Media. Jakarta. 